\title{
Correction to: Water quality evaluation of two urban streams in Northwest Uruguay: are national regulations for urban stream quality sufficient?
}

\author{
Elena Alvareda $(\mathbb{D} \cdot$ - Christine Lucas • Mercedes Paradiso • Adriana Piperno • Pablo \\ Gamazo • Vanessa Erasun • Paola Russo • Andres Saracho • Rafael Banega • Gonzalo \\ Sapriza $\cdot$ Franco Teixeira de Mello (i)
}

Published online: 14 October 2020

(C) Springer Nature Switzerland AG 2020

\section{Correction to: Environ Monit Assess (2020) 192:661 https://doi.org/10.1007/s10661-020-08614-6}

The original version of this article unfortunately contained an error in the published paper.

The online version of the original article can be found at https://doi.org/10.1007/s10661-020-08614-6

E. Alvareda $(\bowtie) \cdot$ C. Lucas · P. Gamazo • V. Erasun ·

P. Russo · A. Saracho · R. Banega · G. Sapriza

Departamento del Agua, Universidad de la República, University Center of Salto, 1350 Salto, Rivera, Uruguay

e-mail: alvareda@fq.edu.uy

C. Lucas

Polo de Ecología Fluvial, Universidad de la República, University Center of Paysandu, Paysandu, Uruguay

M. Paradiso

Unidad de Gestión Ambiental, Paysandu Municipal Government, Sarandí esq. Zorrilla de San Martín., 60000 Paysandú, Uruguay

\section{A. Piperno}

Facultad de Arquitectura Diseño y Urbanismo, Universidad de la República, Br. Artigas, 1031 Montevideo, Uruguay

F. T. de Mello

Departmento de Ecología y Gestión Ambiental, Universidad de la República, CURE Tacuarembó, 20100 Maldonado, Uruguay e-mail: frantei@cure.edu.uy
The paragraph (in page 17): "Recently, TP standards in the main channel of the Uruguay River were raised from 0.025 to $100 \mathrm{mg} / \mathrm{L}$ in association with the consistently high levels of phosphorous registered over time (CARU 2019)".

It should be:

"Recently guideline values for TP in the main channel of Uruguay River were implemented suggesting a maximum standard level of $0.100 \mathrm{mg} / \mathrm{l}$ (CARU, actual guidelines) which is considerably higher to the Uruguayan regulation of $0.025 \mathrm{mg} / \mathrm{l}$ for the National watercourses in Uruguay“"

Publisher's note Springer Nature remains neutral with regard to jurisdictional claims in published maps and institutional affiliations. 